Inga Sina,

Dr. Sc., Professor, EKA University of Applied Sciences, Latvia

(iD) ORCID ID, 0000-0001-6362-6383

email: inga.shina@gmail.com

Aija Sannikova,

Dr. Sc., EKA University of Applied Sciences, Latvia

ORCID ID, 0000-0003-1364-403

email: aija.sannikova@inbox.Iv

Fawad bin Sajjad,

EKA University of Applied Sciences, Latvia

email: fawadbsb2015@gmail.com

Correspondence author: inga.shina@gmail.com

\title{
BRAND OF EUROPEAN HIGHER EDUCATION INSTITUTIONS AS A KEY FACTOR FOR FOREIGN STUDENTS
}

Abstract. This paper summarizes the arguments and counterarguments within the scientific discussion on the issue of brands of European Higher Education Institutions as a key factor for foreign students. The globalization of education processes and the creation of a united European education area have increased foreign students' interest to study in Europe. Increasing unemployment, poverty, inconsistency in education, economic problems, political instability, low job opportunities, and unsafe environment are the undeniable reasons for young students to explore higher education opportunities in foreign countries. The main purpose of the research is to describe the factors affecting foreign students' choice of European Higher Education Institutions and provide information on the factors, which are of great importance. For achieving the aim, the previous research and scientific literature are studied, and a survey is conducted using a questionnaire. Investigation of the topic of brands of European Higher Education Institutions as a key factor for foreign students in the paper is carried out in the following logical sequence: the study of previous research and scientific literature and analysis of the survey results. Methodological tools of the research methods are the creation of a database of respondents, a survey on the factors impacting the choice of Higher Education Institutions in Europe by foreign students and analysis and interpretation of the survey results using nonparametric tests. The object of research is the field of Higher Education in Europe, and the subject of the research is consumer choice in Higher Education in Europe. The paper presents the results of an empirical analysis on brands of European Higher Education Institutions as a key factor for foreign students. It showed that four groups of factors regional, political financial, and educational - play a significant role in the choice of European Higher Education Institutions by foreign students. The research empirically confirms and theoretically proves that the most significant role in the choice of Higher Education Institutions in Europe for all level of students - Bachelor's, Masters and Doctors - play educational factors, the least significant role - political factors. The results of the Kruskal-Wallis $\mathrm{H}$ test show that there are statistically significant differences in the assessment of the role of factors in choosing the place of studies in Europe in different levels of study programs. The results of the research can be useful for decision-makers in Higher Education Institutions in Europe when working out different student attraction strategies, thus increasing the number of students and competitiveness.

Keywords: foreign students, globalization, Higher education, International Business Administration, students' choice.

Introduction. In the EU-28, there were 19.8 million tertiary education (ISCED levels 5-8) students in 2017 (Tertiary education statistics, 2018). Out of them, there were 1.7 million $(8,6 \%)$ students from abroad

Cite as: Sina, I., Sannikova, A., \& bin Sajjad, F. (2020). Brand of European Higher Education Institution as a Key Factor for Foreign Students. Marketing and Management of Innovations, 3, 181-194. http://doi.org/10.21272/mmi.2020.3-13 
who were undertaking tertiary level studies across the EU-28 in 2017. (Tertiary education statistics, 2018). The globalization of education processes and the creation of a united European education area have increased foreign students' interest to study in Europe. Challenges in the labour market in European countries urge them to count foreign student attraction as a possibility for solving an ageing population, maintaining the welfare system, and attracting a skilled workforce. Despite this, the number of foreign students is not significant in Europe. Some countries have introduced research about foreign students' attraction and retention (Arvalstu studentu piesaiste un noturēšana LatvijA, 2018) to solve labour market challenges in Europe. However, there is not enough research about the factors influencing foreign students from third countries' choice of HEI in Europe. There are many overlapping definitions of «international» and «foreign student». Since 2015, UNESCO, OECD and EUROSTAT have agreed on a definition of «international mobile student». An international mobile student is an individual who has physically crossed an international border between two countries to participate in educational activities in a destination country (UNESCO glossary). The main aim of the research is to identify factors affecting foreign students' choice of higher education institute («HE|») in Europe and provide information on the factors, which are of great importance. The research has emerged due to the lack of studies analyzing the factors affecting «third-country national» foreign students to choose European $\mathrm{HEI}$ and the personal engagement of the authors with the organizational, teaching and study process in international programs. Being actively involved in organizing, teaching, and studying, the authors are interested in delivering relevant knowledge on the essential factors for international students choosing an $\mathrm{HEl}$ in Europe and for $\mathrm{HEI}$ to working out different student attraction strategies, thus increasing the number of students and competitiveness. The current research is the continuation of the research «Analysis of the Factors Influencing Foreign Students to Choose European Higher Education Institutions». The research mentioned above exhibited the created questionnaire on the factors, an organized expert group from $\mathrm{HE}$ field and the survey evaluated by the experts. The research questions are:

1) What are the factors influencing foreign students' choice of HEl in Europe?

2) Which factors are of great importance?

Previous studies have identified many factors contributing to a student's decision to study at $\mathrm{HEl}$. However, the extant literature focuses on student perceptions of choice factors in the selection mainly of local HEl. There is some research about Indonesian, Taiwanese and Malaysian students considering factors choosing an HEl at an oversea university in Australia, New Zealand or the United States. Although the literature provides some understanding of factors, it raises concerns about the different factors of student choice for students from different countries. Therefore, this research will explore the main factors for Pakistan students choosing HEl in Europe. The students from Pakistan are chosen because the authors have a good connection with Pakistani students' community in Europe. The research is based on the data collected by means of the survey distributed among the Pakistani students studying in Europe, where 205 responses were obtained. Having analyzed four major groups of factors -regional, political, financial, and educational, out of each group the most influencing factors were detected. The factors which are of great importance were highlighted. Limitations of the research:

1) in this particular research, the Authors are interested in «third-country national» internationally mobile students. According to Council Directive 2004/114/EC «third-country national» means any person who is not a citizen of the European Union (Official Journal of the European Union (2004));

2) the foreign students only from Pakistan are analyzed;

3) calculations were done by four groups of factors. For calculations, the level of the study program (Bachelor, Master, or Doctor) is used as a grouping feature.

This study contributes to a variety of factors that influence the selection of HEl by international students. Exploration of this area is expected to develop an understanding of the theoretical aspects of 
selecting to study abroad and practically implement an understanding of the growth of the HE sector in general.

Literature Review. A lot of the reforms, social, cultural transitions and economic restructuring have been seen across the world during the last time due to the globalization and Informational Technologies development. These changes develop innovative tools, equipment, processes, systems, policies for each European country to stay competitive. The same things happened in the HE sector. Challenges in the labour market in European countries urge them to fight for foreign student attraction. HEl's putting more effort into marketing to identify, communicate and attract new students from foreign countries. Marketing in the HE field has been done for decades. There is a lot of research about potential benefits from marketing in the field of HE marketing worldwide from the late 90s (Kotler and Fox 1995; Hoyt and Brown, 2003; Bragg, 2007; Ivy, 2008; Datar et al., 2010). HEls should use a marketing framework and should satisfy the need of its customers by adding value to achieve sustainable competitive advantage and survive (Hoyt and Brown 2003). At the same time, HE marketing as a service is sufficiently different from the marketing of products (Nicholls et al., 1995). The unique difference which highlights the strength of $\mathrm{HEl}$ should be developed and showed to the potential students as a reason to choose HEI. «Branding is a very common issue for Higher Educational Institutions like other profitable organizations over the last few years» (Alam at al., 2019). There are researches about how university information sources influence advice-seeking attitude, intention, and behaviour between students ( $\mathrm{Ng}$ et al., 2020). Marketing role for student recruitment emphasized several researchers (Ivy, 2001; Goff et al., 2004; Judson et al., 2004; Tapp et al., 2004; Cubillo et al., 2006, Blanco at al., 2019). The variety of factors influencing student choice of $\mathrm{HEl}$ is wide. The researches who studied student decision-making inquire about the influence of different factors - financial, geographic, reputation, personal, influencers. Kusumawati et al. (2010) added that even more - factors have a different level of importance for each country and each student.

Some researchers found that it is a belief of better education in a foreign country over the home country that lead the students to study in another country (Mazzarol and Soutar, 2002). It is the most frequently mentioned reason causing students to choose international education (Mazarrol and Soutar, 2002; Oliveira and Soares, 2016). The lack of good HEl due to economic and political conditions is the main motivation for African students for choosing UK universities (Maringe and Carter's, 2007). Students believe that they will have better job opportunities after getting an education abroad and than leaving the home country (Maringe and Carter, 2007, Blanco et al., 2019, Carstensen et al., 2020). Taking into account these issues, there are a lot of influencing factors for studying abroad - the perception of higher quality overseas education, HEl quality in the home country, influencers, personal development, possibility to get better job. Political stability often is mention as a very important factor when students are choosing the studying country. By political stability, students mean the safety within a country. For example, Chinese student's parents especially consider crime levels (Bodycott, 2009). The location and proximity of the studying country also have a big impact on students' choices (Wu's, 2014). Students preferred countries with a lower cost of living and tuition fees and do not choose countries with extreme weather conditions (Wintre et al.,2015). The very often mentioned factors for choosing the country were to study are the costs, cultural diversity, political stability and location, the image of country (Mazarrol and Soutar, 2002; Wintre et al., 2012; Cheng et al., 2013; Oliveira and Soares, 2016). Important factors affecting the choice of HEI are the reputation of the $\mathrm{HEI}$, programs offered, campus facilities and environment, teaching quality, and employability after graduating. The meaning of the reputation of the $\mathrm{HEI}$ is the recognition nationally or internationally and its ranking (Ancheh et al., 2007, Briggs, 2006). This factor is mentioned in several papers as one of the most important when choosing an HEl (Mazzarol and Soutar, 2002; Maringe and Carter 2007; Kaur, 2016). Chinese students grant high importance on university and course ranking (Wu, 2014). The offered programs by HEl and courses and recognition by future employers also play a big role in students' choice (Wu, 2014). To summarize the literature study about factors affecting different countries 
students choosing the HEl abroad, the authors concluded that factors mentioned are pretty the same, but they are grouped differently.

Methodology and research methods. For achieving the aim, the previous research and scientific literature are studied, and a survey is conducted using a questionnaire. The data was collected from Pakistani students studying in Europe. 205 responses were obtained. Investigation of the topic of brands of European $\mathrm{HEl}$ as a key factor for foreign students in the paper is carried out in the following logical sequence study of previous research and scientific literature and analysis of the survey results. Methodological tools of the research methods are the creation of a database of respondents, a survey on the factors impacting the choice of $\mathrm{HEl}$ in Europe by foreign students and analysis and interpretation of the survey results using nonparametric tests. In the previous research, the authors compared factors influencing regular customer choice (factors affecting customer behaviour) and factors influencing student as a customer choice for choosing HEl. Moreover, they came up with a compilation of the top five factors' groups - regional, political, financial, educational, influencers - and the factors in each group. Experts from the $\mathrm{HE}$ sectors and foreign students who evaluated the questionnaire made some suggestions and factors to add. The authors on purpose leave more factors in each group to better understand which factors are the main ones. Further on these five factors' groups for choosing HEl are matching with factors from the literature and scientific research works done by various authors before. These top factors are presented in Table 1 below.

Table 1. Compilation of Factors influencing students' choice about HEl identified by authors and factors from previous researches

\begin{tabular}{|c|c|c|}
\hline $\begin{array}{l}\text { Factors influencing student choice identified by the } \\
\text { authors }\end{array}$ & $\begin{array}{l}\text { Matching factors influencing } \\
\text { students' choice in previous } \\
\text { studies }\end{array}$ & Researchers \\
\hline $\begin{array}{l}\text { Regional: } \\
\text { 1. Proximity to home country } \\
\text { 2. Weather should be similar to home country } \\
\text { 3. Locals are tolerant towards other religion } \\
\text { 4. Locals are tolerant towards other race } \\
\text { 5. The local politics should not be a threat to } \\
\text { international students } \\
\text { 6. Good Medical facilities } \\
\text { 7. Crime index of the country } \\
\text { 8. Locals can converse in English } \\
\text { 9. Locals are friendly towards foreigners } \\
\text { 10. Family and/or friends already living in that region }\end{array}$ & 2.Geographic location; & $\begin{array}{l}\text { Raposo and Alves, 2007; } \\
\text { Dawes and Brown, 2005; } \\
\text { Wu's, 2014 } \\
\text { Wagner and Fard, 2009; } \\
\text { Beneke and Human, 2010; } \\
\text { Mazarrol \& Soutar, 2002; } \\
\text { Wintre et al., 2012; Cheng et } \\
\text { al., 2013; Oliveira \& Soares, } \\
\text { 2016; } \\
\text { Bodycott, } 2009\end{array}$ \\
\hline $\begin{array}{l}\text { Political: } \\
\text { 1. Duration of the visa process must be quick } \\
\text { 2. Legal part-time job opportunities } \\
\text { 3. Job seeking visa after education } \\
\text { 4. Work permit options after completion of education. } \\
\text { 5. Permanent Residence options are available }\end{array}$ & $\begin{array}{l}\text { 1.Employment prospects; } \\
\text { 2.Employability; } \\
\text { 3.Political conditions; } \\
\text { 4.Better job opportunity; } \\
\text { 5.Political stability }\end{array}$ & $\begin{array}{l}\text { Wiese et al., 2009; } \\
\text { Vevere, V., \& Mons, A.,2020; } \\
\text { Mazarrol \& Soutar, 2002; } \\
\text { Oliveira \& Soares, 2016; Wu, } \\
\text { 2014; } \\
\text { Maringe \& Carter, 2007; } \\
\text { Mazarrol \& Soutar, 2002; } \\
\text { Wintre et al., 2012; Cheng et } \\
\text { al., 2013; Blanco at al., 2019; } \\
\text { Carstensen at al., 2020 } \\
\text { Oliveira \& Soares, } 2016 \\
\end{array}$ \\
\hline $\begin{array}{l}\text { Financial: } \\
\text { 1. Living expense of that country must be affordable } \\
\text { 2. Cost of visa } \\
\text { 3. Travel for visa approval (if the embassy is not in your } \\
\text { region) } \\
\text { 4. Tuition fee for the program } \\
\text { 5. flight ticket and related travel expenses }\end{array}$ & $\begin{array}{l}\text { 1.Cost of living, cost of } \\
\text { education; }\end{array}$ & $\begin{array}{l}\text { Guibourg, 2011; Cubillo, } \\
\text { Sánchez and Cervino, 2006; } \\
\text { Ahmad \& Hussain, 2017; } \\
\text { Sojkin et al., 2012; Wintre et } \\
\text { al.,2015 }\end{array}$ \\
\hline
\end{tabular}




\section{Continued Table 1}

\begin{tabular}{|c|c|c|}
\hline $\begin{array}{l}\text { 6. Availability of Educational Loans in the home country } \\
\text { 7. Family is sponsoring my education } \\
\text { 8. Economic growth of the country }\end{array}$ & $\begin{array}{l}\text { 2. Financial aid or packages that } \\
\text { include scholarships and grants }\end{array}$ & $\begin{array}{l}\text { Govan et al., 2006; Hoyt and } \\
\text { Brown, } 2003\end{array}$ \\
\hline $\begin{array}{l}\text { Educational: } \\
\text { 1. Ranking of the university } \\
\text { 2. Reputation of the university } \\
\text { 3. Accreditation of the program } \\
\text { 4. Facilities in the campus } \\
\text { 5. Educational qualification and work experience of } \\
\text { 6. Accreditation of the university } \\
\text { 7. Accommodation facilities provided } \\
\text { 8. Scholarship opportunities } \\
\text { 9. Internship opportunities } \\
\text { 10. Programs are taught in English } \\
\text { 11. Admission process is easy }\end{array}$ & $\begin{array}{l}\text { 3.Institutional characteristics, } \\
\text { recognition; } \\
\text { 4. Reputation; }\end{array}$ & $\begin{array}{l}\text { Ahmad \& Hussain, 2017; } \\
\text { Sojkin et al., 2012; } \\
\text { Sojkin et al., 2012; Vevere, } \\
\text { V., \& Mons, A.,202; } \\
\text { Tavares et al., 2008; } \\
\text { Mazzarol \& Soutar, 2002; } \\
\text { Maringe \& Carter 2007; Kaur, } \\
2016 \\
\text { Hoyt and Brown, 2003; Wiese } \\
\text { et al., 2009; Beneke and } \\
\text { Human, 2010; Ancheh et al., } \\
\text { 2007; Briggs, 2006 } \\
\text { Mazarrol \& Soutar, 2002; } \\
\text { Oliveira \& Soares, 2016 }\end{array}$ \\
\hline $\begin{array}{ll}\text { Influencers: } \\
\text { 1. } & \text { Family } \\
\text { 2. } & \text { Friends and/or relatives } \\
\text { 3. } & \text { Social Media } \\
\text { 4. } & \text { Education Fair } \\
\text { 5. } & \text { Advertisements } \\
\text { 6. } & \text { Agents and / or Agency } \\
\text { 7. } & \text { Self-interest }\end{array}$ & $\begin{array}{l}\text { 1.Parents; } \\
\text { 2. Friends, peers, relatives, } \\
\text { teachers and other influential } \\
\text { people; } \\
\text { 3.Information provided by HEl; } \\
\text { 4.The motivation of studying, } \\
\text { personal development }\end{array}$ & $\begin{array}{l}\text { Moogan and Baron, 2003; } \\
\text { Raposo and Alves, 2007; } \\
\text { Pimpa and Suwannapirom, } \\
\text { 2008; Wagner and Fard, } \\
\text { 2009); Blanco at al., 2019 } \\
\text { Usunier and Lee, 2009; Alam } \\
\text { at al., 2019; Ng at al., 2020. } \\
\text { Sojkin et al., 2012; } \\
\text { Vevere, V., \& Mons, A.,2020; } \\
\text { Ahmad \& Hussain, } 2017\end{array}$ \\
\hline
\end{tabular}

Sources: developed by the authors.

Based on this table the author's created the questions for questionnaire. The authors' group together factors in four groups - regional, political, financial, educational - and compare the factors inside each group and the most influencing factors in general. The group about influencers were not interpreted using nonparametric tests. It would require another approach, because of two issues - Pakistan is very much a family-oriented culture, and a lot of information from social media should be explored. It could be studied as separate further research. The questionnaire consists of a few sections:

1. Respondent profile. The author's used several, namely, age, gender, marital status, previous qualification.

2. Information, on which study program student, has chosen (Bachelor, Master or Doctoral).

3. Information to what extent do the Regional factors mentioned in the questionnaire affect student choice of HEl.

4. Information to what extent do the Political factors mentioned in the questionnaire affect student choice of HEl.

5. Information to what extent do the Financial factors mentioned in the questionnaire affect student choice of HEl.

6. Information to what extent do the Educational factors mentioned in the questionnaire affect student choice of HEl.

Sections $\mathrm{c}-\mathrm{f}$ are designed based on literature review, and questions are created from Table1 factors. In the questionnaire, there yes/no questions and for evaluation of some statements, respondents are 
offered to use a 5-point Lykert type scale. The opportunities for evaluation vary from 1 - not important till 5 - very important. The authors developed the following research hypotheses:

$\mathrm{H} 1$ : All factors in the top four factor groups - regional, political, financial, educational - play the same role in the choice of the place of studies from European $\mathrm{HEI}$.

$\mathrm{H}$ 2: All sub-factors in each of the top four factor groups play the same role in the choice of the place of studies from European $\mathrm{HEl}$.

According to the selected data from the respondents profile the percentage of respondents according to the age group is as follows: $18-25$ years of age group had the maximum number of respondents with a percentage of $46.3 \%$. The next age group was $26-35$, making up to $31.4 \%$ of respondents and the least number of respondents were from the age group of 35 to 40 , making up to $19.5 \% .81,4 \%$ of students have work experience, and only $18,6 \%$ didn't have any prior work experience. It means that potential students usually start studies after some years of job, they know the field where they want to study. Possibly they pay for their studies by themselves. $60.5 \%$ of the respondents were females, and $39.5 \%$ were males. $62.90 \%$ of the respondents were married, $36.1 \%$ of the respondents were unmarried, and $1 \%$ of the respondents are divorced. These figures show that often married couples decide to go to Europe to study together. It can lead to the suspicion that they possibly do not want to study but only stay in Europe.

Only $19,7 \%$ of students have visited Europe before. From the survey respondents 22 members have applied for studies in Latvia, 15 members have applied for Demark, 13 for Germany, 11 for Estonia, 9 for Spain, 8 for Finland, 6 for England, 6 for Italy, 4 for Iceland, 3 for Poland, 2 for Holland, 1 for Hungary.

The research shows that $45.90 \%$ have applied for Bachelor's level of education. One third $(36,1 \%)$ of students have a Bachelor's level of education completed. They wish to receive a Master's degree in Europe. That means that the marketing campaign should be addressed either for school graduates or students with a Bachelor's degree. The families and friends have a strong influence on the potential students in Pakistan. Information from social media cannot be taken $100 \%$ true in Pakistan. But its influence cannot be ignored. Education fairs are the platforms to meet various countries' $\mathrm{HEI}$ representatives. It is a source of accurate information. The potential students actively search for information about $\mathrm{HEI}$, the process to get in onto the $\mathrm{HEl}$, countries where to study from an independent and experienced source. There are working educational agencies and individual agents. The level of their services is not very high in Pakistan.

Results. The descriptive statistics results of online surveys are analyzed, interpreted, and graphically presented. Each factor is analyzed separately. Regional factors: it is shown that the minimum and maximum values of ratings received are between the range of 1 (very low) to 5 (very high) for Regional factors. The graphical presentation above (Figure 1) shows that a total of ten factors were studied. The mean values range from 3.91 to 4.39 . The value of the standard deviation ranges from 0.561 to 0.901 . The highest mean value of 4.39 is scored for the factor "Crime index of the country». The lowest mean value of 3.91 is scored for the factor "Weather should be similar to the home country». Therefore, the weather does not play a significant role in the choice of destination. The highest standard deviation is scored of 0.901 for the variable «Proximity to the home country». It indicates that the opinion of the respondents is more spread out.

The graphical presentation above (see Fig. 2) shows that 5 variables were studied. The mean value ranges from 3.88 to 4.27 . The standard deviation values range from 0.563 to 0.78 . The highest mean value of 4.27 has been scored for the variable «Permanent Residence options are available». This indicates that the majority of students agree on it. And the lowest mean score of 3.88 has been scored for the variable «Duration of the visa process must be quick». It indicates that students do not consider this fact as important. The above graph (Figure 3 ) shows a total of 8 variables studied. The mean values range from 4.07 to 4.42 . The highest mean score of 4.42 has been obtained for the variable «Travel for visa approval (if the embassy is not in your region)». 

2. Wheather should be similar to home country

3. Locals are tolerant towards other religion

4. Locals are tolerant towards other race

5. The local politics should not be a thread 6. Good Medical facilities 7. Crime index

8. Locals can converse in English 9. Locals atr friendly towards foreigners

10. Family and friends already living in that region

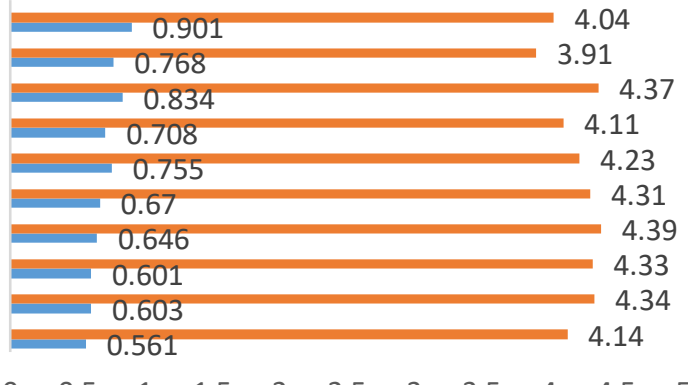

- Standart Deviation $\quad$ Mean

Figure 1. Descriptive Statistics Results for Regional factors from Online survey Sources: systematized by the authors.

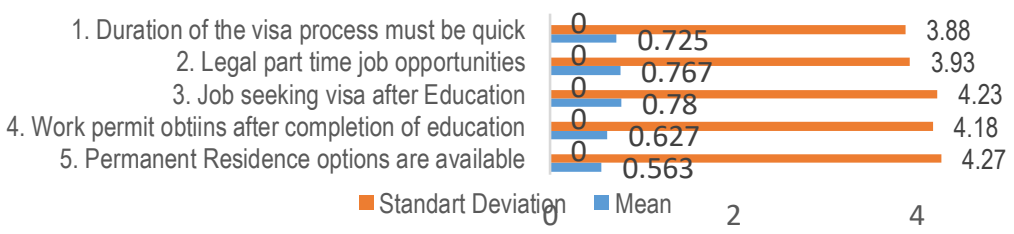

Figure 2. Descriptive Statistics Results for Political factors from Online survey Sources: systematized by the authors.

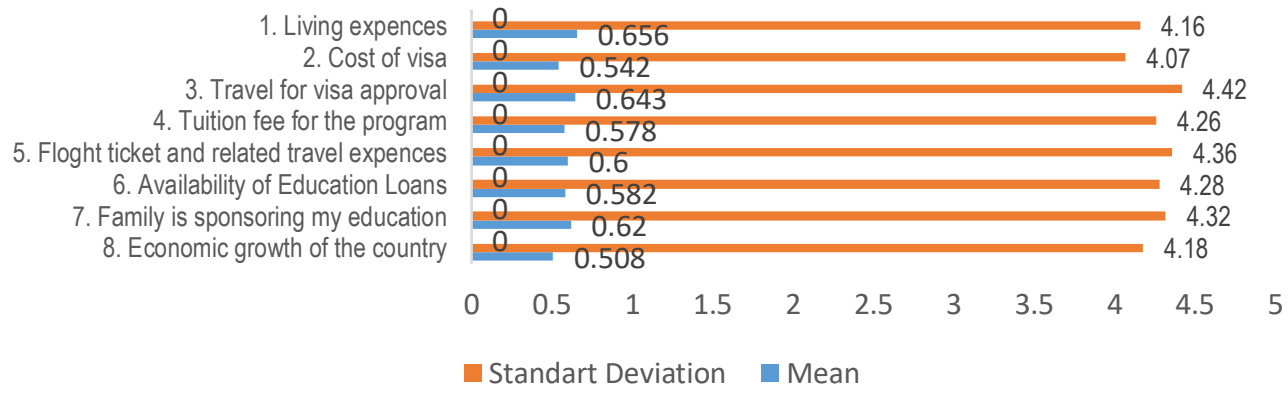

Figure 3. Descriptive Statistics Results for Financial factors from Online survey Sources: systematized by epy authors.

The majority of the students agree that if the embassy is not in the region, travel for a visa is a significant financial factor. The low mean score of 4.07 has been scored for the variable "Cost of visa». It could show that students understand that they have to pay for the visa only once. The standard deviation values range from 0.508 to 0.656 . The highest standard deviation with a score of 0.656 has been scored for the variable "Living expense in the country» indicating that people have varied opinions on this. The lowest standard deviation has been scored for 0.508 for the variable «Economic growth of the country», indicating that students have agreed on it. 


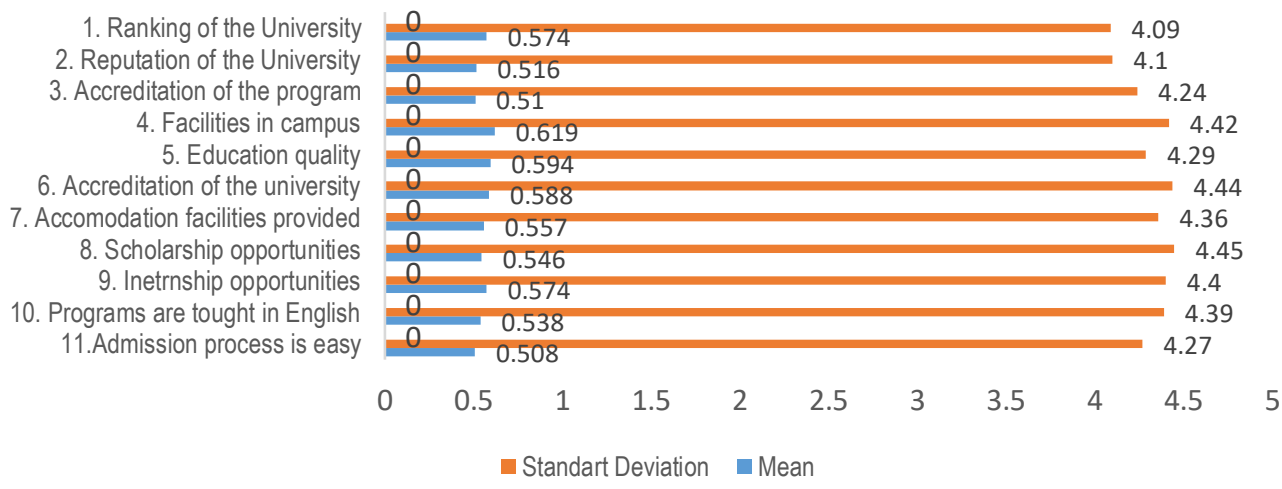

Figure 4. Descriptive Statistics Results for Educational factors from Online survey Sources: systematized by the authors.

The above graph (Figure 4) shows that a total of 11 variables were studied. The mean scores range from 4.09 to 4.45 . The lowest mean score of 4.09 has been obtained for the variable «Ranking of the university». It indicated that Pakistani students do not think that the ranking of the HEl is unimportant to study abroad. The highest mean of 4.45 has been scored for the variable «Scholarship opportunities». It clearly shows that scholarship is significant for students. The standard deviation scores range from 0.508 to 0.619 . The lowest standard deviation scored is 0.508 for the variable «Admission process is easy» and it is closer to the mean value. The highest standard deviation has been obtained for the variable «Facilities in the campus» with a score of 0.619 . It shows that students vary in their opinion regarding facilities in the $\mathrm{HEI}$ campus to be considered a priority. To sum up, the results of descriptive statistics, considering all the four factors - Regional, Political, Financial, Educational - the mean values range from 3.87 to 4.49 and the ratings received range from 1 to 5 .

Table 2. Summary of Mean values in Descriptive Statistics Results from an online survey

\begin{tabular}{|c|c|c|c|c|c|}
\hline No. & Factor & $\begin{array}{c}\text { Highest Standard Deviation } \\
\text { scored for the variable }\end{array}$ & $\begin{array}{c}\text { Lowest Standard } \\
\text { Deviation Scored for } \\
\text { the variable }\end{array}$ & Lowest & Highest \\
\hline 1 & Regional & Crime index of the country & $\begin{array}{c}\text { Weather should be } \\
\text { similar to home country }\end{array}$ & 3.91 & 4.39 \\
\hline 2 & Political & $\begin{array}{c}\text { Permanent Residence options } \\
\text { are available }\end{array}$ & $\begin{array}{c}\text { Duration of the visa } \\
\text { process must be quick }\end{array}$ & 3.88 & 4.27 \\
\hline 3 & Financial & $\begin{array}{c}\text { Travel for visa approval (if the } \\
\text { embassy is not in your region) }\end{array}$ & Cost of visa & 4.07 & 4.42 \\
\hline 4 & Educational & Scholarship opportunities & $\begin{array}{c}\text { Ranking of the } \\
\text { university }\end{array}$ & 4.09 & 4.45 \\
\hline
\end{tabular}

Sources: developed by the authors.

The above table shows that the highest mean value of 4.49 has been scored for the variable «Availability of Educational Loans in home country» belongs to the Financial factor. And the lowest mean of 3.87 has been scored for the variable «Weather should be similar to the home country» belonging to the Regional factor. It could be concluded that students think more about financial aspects before choosing $\mathrm{HEl}$. 
Table 3. Summary of Mean values in Descriptive Statistics Results from an online survey

\begin{tabular}{|c|c|c|c|c|c|}
\hline No. & Factor & $\begin{array}{c}\text { Highest Standard } \\
\text { Deviation scored for the } \\
\text { variable }\end{array}$ & $\begin{array}{c}\text { Lowest Standard } \\
\text { Deviation Scored for the } \\
\text { variable }\end{array}$ & \multicolumn{2}{|c|}{ Score range } \\
\cline { 5 - 6 } & Regional & Proximity to home country & $\begin{array}{c}\text { Family and/ or friends } \\
\text { already live in that region. }\end{array}$ & 0.561 & 0.901 \\
\hline 2 & Political & $\begin{array}{c}\text { Job seeking visa after } \\
\text { education }\end{array}$ & $\begin{array}{c}\text { Permanent Residence } \\
\text { options are available }\end{array}$ & 0.563 & 0.780 \\
\hline 3 & Financial & $\begin{array}{c}\text { Living expense of the } \\
\text { country }\end{array}$ & $\begin{array}{c}\text { The economic growth of the } \\
\text { country }\end{array}$ & 0.508 & 0.656 \\
\hline 4 & Educational & Facilities in the campus & $\begin{array}{c}\text { The admission process is } \\
\text { easy }\end{array}$ & 0.508 & 0.619 \\
\hline 5 & Personality & I need family and/or \\
friends around me & $\begin{array}{c}\text { I can manage my stress } \\
\text { level }\end{array}$ & 0.516 & 0.695 \\
\hline
\end{tabular}

Source: developed by authors.

The highest standard deviation with a score of 0.914 for the variable «Proximity to the home country» belonged to the Regional factor. Herewith, the least standard deviation has been scored for the 0.359 to «Reputation of the university» belonging to the Educational factor. It could be concluded that the students have a similar opinion than the Educational factors are more important than the Regional factor.

1. A nonparametric Kruskal-Wallis $\mathrm{H}$ test allowed testing the hypothesis that all factors in the top four factors groups and all sub-factors in each of the top four factors groups play the same role in the choice of the place of studies from European $\mathrm{HEl}$. This test is based on the average ranking comparison.

2. Assessment of regional factors (RF1-RF10).

Table 4. Assessment of regional factors

\begin{tabular}{|c|c|c|c|c|c|c|}
\hline \multirow{3}{*}{$\begin{array}{l}\text { Regional } \\
\text { factors }\end{array}$} & \multicolumn{6}{|c|}{ Program } \\
\hline & \multicolumn{2}{|c|}{ Bachelors } & \multicolumn{2}{|c|}{ Master } & \multicolumn{2}{|c|}{ Doctoral } \\
\hline & $\begin{array}{c}\text { Tests } \\
\text { statistics }\end{array}$ & $\begin{array}{l}\text { Mean } \\
\text { Rank }\end{array}$ & $\begin{array}{c}\text { Tests } \\
\text { statistics }\end{array}$ & Mean Rank & $\begin{array}{c}\text { Tests } \\
\text { statistics }\end{array}$ & $\begin{array}{l}\text { Mean } \\
\text { Rank }\end{array}$ \\
\hline RF1 & \multirow{10}{*}{$\begin{array}{c}\text { Kruskal- } \\
\text { Wallis H: } \\
67.197 ; \\
p=0.000\end{array}$} & 406.19 & \multirow{10}{*}{$\begin{array}{c}\text { Kruskal- } \\
\text { Wallis H: } \\
29.002 ; \\
p=0.001\end{array}$} & 29.002 & \multirow{10}{*}{$\begin{array}{c}\text { Kruskal- } \\
\text { Wallis H: } \\
\text { 13.161; } \\
p=0.155\end{array}$} & 216.07 \\
\hline RF2 & & 358.82 & & 263.27 & & 176.16 \\
\hline RF3 & & 554.45 & & 372.84 & & 239.27 \\
\hline RF4 & & 407.42 & & 299.51 & & 201.59 \\
\hline RF5 & & 490.65 & & 318.08 & & 215.51 \\
\hline RF6 & & 465.36 & & 350.18 & & 246.68 \\
\hline RF7 & & 562.36 & & 336.59 & & 239.58 \\
\hline RF8 & & 458.21 & & 363.40 & & 225.76 \\
\hline RF9 & & 526.70 & & 320.68 & & 229.16 \\
\hline RF10 & & 419.78 & & 278.06 & & 210.66 \\
\hline
\end{tabular}

Sources: developed by the authors.

The study shows that in the group of regional factors with a probability of $95 \%$ it can be stated that Bachelor programs $(p=0.000)$ students and Master's programs $(p=0.001)$ students evaluate differently the regional factor. Bachelor's students give a more important role in the following factors:

- Crime index of the country (Mean Rank= 562,36).

- Locals are tolerant towards other religion (Mean Rank= 554,45).

- Locals are friendly towards foreigners (Mean Rank=526.70).

Master's program students consider that the most important factors are: 
- Locals can converse in English (Mean Rank= 372,84).

- Locals are tolerant towards other religion (Mean Rank=372,84).

- Good Medical facilities (Mean Rank= 350,18), but the factor «Proximity to the home country» (Mean Rank $=29.002$ ) is considered to be the least important.

3. In doctoral study programs, students assign a higher role to the factor «Good Medical facilities» (Mean Rank $=246.68$ ) and the factor "Locals are tolerant towards other race» (Mean Rank $=239.58$ ). However, it is concluded that there was no statistically significant difference in the assessment of regional factors considering that the $p$-value of the Kruskal-Wallis $\mathrm{H}$ test is $p=0.155$.

4. Assessment of political factors (PF11 - PF15). Respondents' answers show a statistically significant difference in the assessment of political factors in all programs. The factor «Job seeking visa after Education» received the highest rating for the Bachelors' students (Mean Rank = 265.51) and Master's students (Mean Rank = 176.50). At the same time, doctoral students rated the factor «Permanent Residence options are available» (Mean Rank $=120.89$ ) as more important.

Table 5. Assessment of political factors

\begin{tabular}{|c|c|c|c|c|c|c|}
\hline \multirow{3}{*}{$\begin{array}{l}\text { Political } \\
\text { factors }\end{array}$} & \multicolumn{6}{|c|}{ Program } \\
\hline & \multicolumn{2}{|c|}{ Bachelors } & \multicolumn{2}{|c|}{ Master } & \multicolumn{2}{|c|}{ Doctoral } \\
\hline & $\begin{array}{c}\text { Tests } \\
\text { statistics }\end{array}$ & $\begin{array}{l}\text { Mean } \\
\text { Rank }\end{array}$ & $\begin{array}{c}\text { Tests } \\
\text { statistics }\end{array}$ & $\begin{array}{l}\text { Mean } \\
\text { Rank }\end{array}$ & $\begin{array}{c}\text { Tests } \\
\text { statistics }\end{array}$ & $\begin{array}{l}\text { Mean } \\
\text { Rank }\end{array}$ \\
\hline PF11 & \multirow{5}{*}{$\begin{array}{l}\text { Kruskal- } \\
\text { Wallis H: } \\
36.092 ; \\
\mathrm{p}=0.000\end{array}$} & 186.43 & \multirow{5}{*}{$\begin{array}{l}\text { Kruskal- } \\
\text { Wallis H: } \\
\text { 14.910; } \\
\mathrm{p}=0,005\end{array}$} & 136.83 & \multirow{5}{*}{$\begin{array}{c}\text { Kruskal- } \\
\text { Wallis H: } \\
9.485 \\
\mathrm{p}=0.05\end{array}$} & 98.15 \\
\hline PF12 & & 205.17 & & 143.23 & & 97.15 \\
\hline PF13 & & 265.51 & & 176.50 & & 123.48 \\
\hline PF14 & & 242.09 & & 173.39 & & 112.84 \\
\hline PF15 & & 265.81 & & 172.55 & & 120.89 \\
\hline
\end{tabular}

Sources: developed by the authors.

5. Evaluation of financial factors (FF16 - FF23). The answers of the respondents show a statistically significant difference in the assessment of political factors for students of Bachelor's programs and students of Master's programs. The factor «Travel for visa approval if the embassy is not in your region» and factor are the most important factors choosing the studies for Bachelor's programs and Master's program students. Doctor study program students as the most important factor mentioned «Availability of Educational Loans in the home country» and «Travel for all approval if the embassy is not in your region». However, considering that the test $p=0.089$, it can be concluded that these differences are random.

Table 6. Assessment of financial factors

\begin{tabular}{|c|c|c|c|c|c|c|}
\hline \multirow{3}{*}{$\begin{array}{l}\text { Financial } \\
\text { factors }\end{array}$} & \multicolumn{6}{|c|}{ Program } \\
\hline & \multicolumn{2}{|c|}{ Bachelors } & \multicolumn{2}{|c|}{ Master } & \multicolumn{2}{|c|}{ Doctoral } \\
\hline & $\begin{array}{c}\text { Tests } \\
\text { statistics }\end{array}$ & $\begin{array}{l}\text { Mean } \\
\text { Rank }\end{array}$ & $\begin{array}{c}\text { Tests } \\
\text { statistics }\end{array}$ & Mean Rank & $\begin{array}{c}\text { Tests } \\
\text { statistics }\end{array}$ & $\begin{array}{l}\text { Mean } \\
\text { Rank }\end{array}$ \\
\hline FF16 & \multirow{8}{*}{$\begin{array}{c}\text { Kruskal- } \\
\text { Wallis H: } \\
26.785 \\
\mathrm{P}=0.000\end{array}$} & 324.35 & \multirow{8}{*}{$\begin{array}{l}\text { Kruskal- } \\
\text { Wallis H: } \\
26.834 ; \\
P=0.000\end{array}$} & 239.28 & \multirow{8}{*}{$\begin{array}{c}\text { Kruskal- } \\
\text { Wallis H: } \\
\text { 12.386; } \\
p=0.089\end{array}$} & 179.41 \\
\hline FF17 & & 328.91 & & 210.07 & & 140.72 \\
\hline FF18 & & 423.33 & & 298.57 & & 195.45 \\
\hline FF19 & & 376.43 & & 265,38 & & 169.91 \\
\hline FF20 & & 412.46 & & 285.60 & & 174.57 \\
\hline FF21 & & 381.26 & & 241.94 & & 197.52 \\
\hline FF22 & & 388.70 & & 281.47 & & 176.33 \\
\hline FF23 & & 336.22 & & 226.16 & & 178.09 \\
\hline
\end{tabular}

Sources: developed by the authors. 
6. Assessment of educational factors (EF24 -EF34). Respondents' answers show a statistically significant difference in the assessment of educational factors in all programs. Bachelor students rated higher such factors as «Accommodation facilities provided» (Mean Rank $=744.50$ ), «Internship opportunities» (Mean Rank $=530.49$ ) and «Facilities in the campus (latest technology used for teaching, library, cafeteria, etc.)» (Mean Rank $=530.49$ ). Master's students rated higher such factors as «Scholarship opportunities» (Mean Rank $=385.64$ ) and «Educational qualification and work experience of teaching staff» (Mean Rank = 380.41). Doctoral students as the higher-rated factors mention «Facilities in the campus (latest technology used for teaching, library, cafeteria, etc.)" (Mean Rank = 277.52), «Accreditation of the university» (Mean Rank $=272.45$ ) and «Scholarship opportunities» (Mean Rank = 272.45).

Table 7. Assessment of educational factors

\begin{tabular}{|c|c|c|c|c|c|c|}
\hline \multirow{3}{*}{$\begin{array}{l}\text { Educational } \\
\text { factors }\end{array}$} & \multicolumn{6}{|c|}{ Program } \\
\hline & \multicolumn{2}{|c|}{ Bachelors } & \multicolumn{2}{|c|}{ Master } & \multicolumn{2}{|c|}{ Doctoral } \\
\hline & $\begin{array}{c}\text { Tests } \\
\text { statistics }\end{array}$ & $\begin{array}{l}\text { Mean } \\
\text { Rank }\end{array}$ & $\begin{array}{c}\text { Tests } \\
\text { statistics }\end{array}$ & Mean Rank & $\begin{array}{c}\text { Tests } \\
\text { statistics }\end{array}$ & $\begin{array}{l}\text { Mean } \\
\text { Rank }\end{array}$ \\
\hline EF24 & \multirow{7}{*}{$\begin{array}{c}\text { Kruskal- } \\
\text { Wallis H: } \\
53.993 ; \\
\mathrm{p}=0.000\end{array}$} & 381.52 & \multirow{7}{*}{$\begin{array}{l}\text { Kruskal- } \\
\text { Wallis H: } \\
33.493 \text {; } \\
p=0.000\end{array}$} & 273.67 & \multirow{7}{*}{$\begin{array}{l}\text { Kruskal- } \\
\text { Wallis H: } \\
32.875 \\
p=0.000\end{array}$} & 203.70 \\
\hline EF25 & & 363.29 & & 301.89 & & 187.89 \\
\hline EF26 & & $420 ., 93$ & & 342.02 & & 210.68 \\
\hline EF27 & & 517.62 & & 376.77 & & 277.52 \\
\hline EF28 & & 439.35 & & 380.41 & & 210.95 \\
\hline EF29 & & 509.32 & & 401.34 & & 272.45 \\
\hline EF30 & & 744.50 & & 345.36 & & 258.40 \\
\hline EF31 & & 483.95 & & 385.64 & & 272.45 \\
\hline EF32 & & 530.49 & & 367.89 & & 270.70 \\
\hline EF33 & & 486.96 & & 377.22 & & 249.61 \\
\hline EF34 & & 494.62 & & 319.64 & & 253.13 \\
\hline
\end{tabular}

Sources: developed by the authors.

7. All factors together. The results of the Kruskal-Wallis $\mathrm{H}$ test show that:

- there are statistically significant differences in the assessment of the role of factors in choosing the place of studies in Europe in all levels of study programs;

- factors related to education play the most significant role in the choice of the place of studies in Europe in all levels of study programs

Table 8. Assessment of all factors

\begin{tabular}{|c|c|c|c|c|c|c|}
\hline \multirow{3}{*}{ Factor groups } & \multicolumn{6}{|c|}{ Program } \\
\hline & \multicolumn{2}{|c|}{ Bachelors } & \multicolumn{2}{|c|}{ Master } & \multicolumn{2}{|c|}{ Doctoral } \\
\hline & $\begin{array}{c}\text { Tests } \\
\text { statistics }\end{array}$ & Mean Rank & $\begin{array}{c}\text { Tests } \\
\text { statistics }\end{array}$ & Mean Rank & $\begin{array}{c}\text { Tests } \\
\text { statistics }\end{array}$ & $\begin{array}{l}\text { Mean } \\
\text { Rank }\end{array}$ \\
\hline Regional factors & \multirow{4}{*}{$\begin{array}{l}\text { Kruskal- } \\
\text { Wallis H: } \\
32.582 ; \\
p=0.000\end{array}$} & 1527.63 & \multirow{4}{*}{$\begin{array}{c}\text { Kruskal- } \\
\text { Wallis H: } \\
9.453 ; \\
p=0.024\end{array}$} & 1089.59 & \multirow{4}{*}{$\begin{array}{c}\text { Kruskal- } \\
\text { Wallis H: } \\
16.569 ; \\
p=0.001\end{array}$} & 740.09 \\
\hline Political factors & & 1365.02 & & 1006.43 & & 671.26 \\
\hline Financial factors & & 1531.87 & & 1088.67 & & 742.72 \\
\hline $\begin{array}{l}\text { Educational } \\
\text { factors }\end{array}$ & & 1617.13 & & 1118.56 & & 793.89 \\
\hline
\end{tabular}

Source: developed by the authors. 
Conclusions. The aim of the paper «to describe the factors affecting foreign students to choose European $\mathrm{HEl}$ and provide information on the factors, which are of great importance» was achieved. The first hypothesis of the research «All factors in the top four factor groups - regional, political, financial, educational - play the same role in the choice of the place of studies from European $\mathrm{HEl}$ » and the second hypothesis of the research «All sub-factors in each of the top four factor groups play the same role in the choice of the place of studies from European HEl» were rejected. There are Limitations of the research the author's are interested in «third-country national» internationally mobile students; the foreign students only from Pakistan are analyzed; for calculations, the level of the study program (Bachelor, Master, or Doctor) is used as a grouping feature. The author's findings correlate with the authors of previous researches to a great extent. Moreover, they provide information on the factors affecting foreign students to choose European $\mathrm{HEl}$ and which are of great importance to foreign students. The results of the paper should be used for HEI decision-makers working out different student attraction strategies, thus increasing the number of students and competitiveness. Four groups of factors - regional, political financial, and educational- were analyzed. The research shows that the most significant role in the choice of the place of studies in Europe for all level of foreign students plays educational factors, the least considerable role - political factors. The results of the Kruskal-Wallis $\mathrm{H}$ test show that there are statistically significant differences in the assessment of the role of factors in choosing the place of studies in Europe in different levels of study programs. From Regional factors for Bachelor's students, the most critical factor is «Crime index of the country», for Master students - "Locals can converse in English», for Doctoral students "Good Medical facilities». In case of political factors for Bachelor's and Master students, the most critical factor is «Job seeking visa after education», for Doctoral students - «Permanent Residence options are available». From Financial factors, for Bachelor's and Master students, the most important factor is «Flight ticket and related travel expenses», for Doctoral students - «Availability of Educational Loans».

This study contributes to a variety of factors that influence the selection of HEl by international students. Exploration of this area is expected to develop an understanding of the theoretical aspects of selecting to study abroad and practically implement an understanding of the growth of the HE sector in general. Based on the same survey, the authors are planning to continue the research about the students' choices from the next countries and then to compare the results.

Author Contributions: Conceptualization, I. S.; methodology, I. S.; validation, A. S.; formal analysis, A. S.; investigation, F. b. S.; resources, I. S.; data curation, I. S.; supervision, I. S.; project administration, I. S.

Funding: This research received no external funding.

\section{References}

Ahmad, S. Z., \& Hussain, M. (2017). An investigation of the factors determining student destination choice for higher education in the United Arab Emirates. Studies in Higher Education, 42(7), 1324-1343. [Google Scholar] [CrossRef]

Alam, M. I., Faruq, M. O., Alam, M. Z., \& Gani, M. O. (2019). Branding Initiatives in Higher Educational Institutions: Current Issues and Research Agenda.Marketing and Management of Innovations, 1, 34-45. [Google Scholar] [CrossRef]

Ancheh, K. S. B., Krishnan, A. \& Nurtjagja, O. (2007). Evaluative criteria for selection of private universities and colleges in Malaysia. Journal of International Management Studies, 2(1), 1-11.

Arvalstu studentu piesaiste un noturēšana LatvijA, izpētes zinojums (2018). Retrieved from http://www.emn.lv/wpcontent/uploads/Atracting-international-students final_LV.pdf

Beneke, J., \& Human, G. (2010). Student recruitment marketing in South Africa An exploratory study into the adoption of a relationship orientation. African Journal of Business Management, 4(4), 435-447. [Google Scholar] [CrossRef]

Blanco, M., Bares, L., \& Hrynevych, O. (2019). University Brand as a Key Factor of Graduates Employment. Marketing and Management of Innovations, 3, 193-208. [Google Scholar] [CrossRef]

Bodycott, P. (2009). Choosing a higher education study abroad destination: What mainland Chinese parents and students rate as important. Journal of research in International education, 8(3), 349-373. [Google Scholar] [CrossRef] 


\section{I., Sina, A., Sannikova, F., bin Sajjad. Brand of European Higher Education Institution as a Key Factor for Foreign Students}

Bragg, S. (2007). «Student voice» and governmentality: The production of enterprising subjects?. Discourse: studies in the cultural politics of education, 28(3), 343-358. [Google Scholar] [CrossRef]

Branco Oliveira, D., \& Soares, A. M. (2016). Studying abroad: Developing a model for the decision process of international students. Journal of Higher Education Policy and Management, 38(2), 126-139. [Google Scholar] [CrossRef]

Briggs, S. (2006). An exploratory study of the factors influencing undergraduate student choice: the case of higher education in Scotland. Studies in Higher Education, 31(6), 705-722. [Google Scholar] [CrossRef]

Carstensen, V., Happ, R., \& Zlatkin-Troitschanskaia, O. (2020). Second-Generation Immigrants' Entry into Higher Education: Students' Enrollment Choices at Different Types of Universities. Eastern Economic Journal, 46(1), 126-160. [Google Scholar] [CrossRef]

Cubillo, J. M., Sánchez, J., \& Cerviño, J. (2006). International students' decision-making process. International Journal of Educational Management. [Google Scholar] [CrossRef]

Datar, S. M., Garvin, D. A., Cullen, P. G., \& Cullen, P. (2010). Rethinking the MBA: Business education at a crossroads. Harvard Business Press. [Google Scholar]

Dawes, P. L., \& Brown, J. (2005). The composition of consideration and choice sets in undergraduate university choice: An exploratory study. Journal of Marketing for Higher Education, 14(2), 37-59. [Google Scholar] [CrossRef]

Gibbs, P., Pashiardis, P., \& Ivy, J. (2008). A new higher education marketing mix: the 7Ps for MBA marketing. International Journal of educational management. [Google Scholar] [CrossRef]

Goff, B., Patino, V., \& Jackson, G. (2004). Preferred information sources of high school students for community colleges and universities. Community College Journal of Research \& Practice, 28(10), 795-803. [Google Scholar] [CrossRef]

Govan, G. V., Patrick, S., \& Yen, C. J. (2006). How high school students construct decision-making strategies for choosing colleges. College and University, 81(3), 19. [Google Scholar]

Guibourg, C. (2011). New fees prompt fears of cuts at Swedish universities. The Local-Sweden's news in English. Retrieved from https://www.thelocal.se/20110822/35690

Hoyt, J. E., \& Brown, A. B. (2003). Identifying college choice factors to successfully market your institution. College and university, 78(4), 3. [Google Scholar]

Cheng, M. Y., Mahmood, A., \& Yeap, P. F. (2013). Malaysia as a regional education hub: a demand-side analysis. Journal of Higher Education Policy and Management, 35(5), 523-536. [Google Scholar] [CrossRef]

Kotler, P., \& Fox, K. F. (1995). Strategic marketing for educational institutions. Prentice Hall. [Google Scholar]

Kusumawati, A., Yanamandram, V. K., \& Perera, N. (2010). University marketing and consumer behaviour concerns: the shifting preference of university selection criteria in Indonesia. Asian Studies Association of Australia 18th Biennial Conference, 1-16. [Google Scholar]

Maringe, F., \& Carter, S. (2007). International students' motivations for studying in UK HE. International Journal of Educational Management. [Google Scholar] [CrossRef]

Mazzarol, T., \& Soutar, G. N. (2002). "Push-pull" factors influencing international student destination choice. International Journal of Educational Management, 16(2), pp.82-90. [Google Scholar] [CrossRef]

Moogan, Y. J., \& Baron, S. (2003). An analysis of student characteristics within the student decision making process. Journal of further and Higher Education, 27(3), 271-287. [Google Scholar] [CrossRef]

$\mathrm{Ng}$, P., Lee, D., Wong, P., \& Lam, R. (2020). Making a higher education institution choice: differences in the susceptibility to online information on students' advice-seeking behavior. Online Information Review, 44(4), 847-861. [Google Scholar] [CrossRef]

Nicholls, J., Harris, J., Morgan, E., Clarke, K., \& Sims, D. (1995). Marketing higher education: the MBA experience. International Journal of Educational Management, 9(2), 31-38. [Google Scholar] [CrossRef]

Pimpa, N., \& Suwannapirom, S. (2008). Thai students' choices of vocational education: marketing factors and reference groups. Educational Research for Policy and Practice, 7(2), 99-107. [Google Scholar] [CrossRef]

Raposo, M., \& Alves, H. (2007). A model of university choice: an exploratory approach. University Library of Munich, Germany. [Google Scholar]

Singh, M. K. M. (2016). Socio-Economic, Environmental and Personal Factors in the Choice of Country and Higher Education Institution for Studying Abroad among International Students in Malaysia. International Journal of Educational Management, 30(4), 505-519. [Google Scholar] []

Sojkin, B., Bartkowiak, P., \& Skuza, A. (2012). Determinants of higher education choices and student satisfaction: the case of Poland. Higher education, 63(5), 565-581. [Google Scholar]

Tavares, D., Tavares, O., Justino, E., \& Amaral, A. (2008). Students' preferences and needs in Portuguese higher education. European Journal of Education, 43(1), 107-122. [Google Scholar] [CrossRef]

Usunier, J. C., \& Lee, J. A. (2009). Marketing Across Cultures (5th ed.). Harlow, England: Pearson Education Limited.

Van Heerden, N., Wiese, M., North, E., \& Jordaan, Y. (2009). A marketing perspective on choice factors considered by South African first-year students in selecting a higher education institution. Southern African Business Review, 13(1), 39-60. [Google Scholar]

Vevere, V., \& Mons, A. (2020). Applying behavioural economics in education: study of undergraduate practices of selecting higher educational institutions. In SHS Web of Conferences (Vol. 74, p. 01035). EDP Sciences. [Google Scholar] [CrossRef] 


\section{I., Sina, A., Sannikova, F., bin Sajjad. Brand of European Higher Education Institution as a Key Factor for Foreign Students}

Wagner, K., \& Fard, P. Y. (2009). Factors influencing Malaysian students' intention to study at a higher educational institution. ELeader Kuala Lumpur. [Google Scholar]

Wu, Q. (2014). Motivations and decision-making processes of mainland Chinese students for undertaking Master's programs abroad. Journal of Studies in International Education, 18(5), 426-444. [Google Scholar] [CrossRef]

Iнга Сіна, Dr. Sc, профеесор, Університет Економіки та культури, Латвія

Айя Саннікова, Dr. Sc., Університет Економіки та культури, Латвія

Фавад бін Саджад, Університет Економіки та культури, Латвія

Бренд Європейських закладів вищої освіти як ключовий фактор залучення іноземних студентів

У статті досліджено специфріку формування та промоції бренду закладів вищої освіти (3ВО) в Європі серед іноземних студентів. Авторами зазначено, що глобалізація та створення єдиного європейського освітнього простору спровокували зростання рівня зацікавленості іноземних студентів до навчання в європейських $3 В О$. Встановлено, що загострення економічних проблем, зростання рівня безробіття та бідності, політична нестабільність, низькі можливості працевлаштування, а також загострення екологічних проблем є головними причинами пошуку можливостей вступу до іноземних ЗВО. Головною метою статmі $є$ визначення факторів, які впливають на вибір іноземних студентів вступати до зВО Європи. Для досягнення поставленої мети, аналіз здійснено в наступній логічній послідовності: 1) систематизовано попередні наукові напрацювання з досліджуваної проблематики; 2) проаналізовано результати опитування респондентів. Методологічним інструментарієм даного дослідження $\epsilon$ створення бази даних респондентів; дослідження факторів, які впливають на вибір іноземних студентів навчатись в європейських 3ВО; аналіз та інтерпретаиія результатів опитування за допомогою непараметричних тестів. За результатами емпіричного дослідження встановлено, що бренд європейських ЗВО є головним фактором, який впливає на вибір іноземних студентів. Авторами виокремилено чотири групи факторів, які мають статичтично значущий вплив на вибір іноземних студентів європейського ЗВО, а саме: регіональні, політичні фінансові та освітні. Емпіричні результати засвідчили, що головну роль при виборі Європейського ЗВО для студентів усіх освітніх рівнів (бакалавр, магістр та доктор фрілософії) відіграє якість освітніх послуг. При иьому найменший вплив мають політичні фрактори. За результатами тесту Крускала-Уолліса встановлено, що існують статистично значущі відмінності в силі впливу факторів на вибір місия навчання в Європі для різних рівнів навчальних програм. Результати дослідження можуть бути корисними особам, які приймають рішення щодо фоормування стратегій залучення іноземних студентів та зростання конкурентоспроможності зВО.

Ключові слова: іноземні студенти, глобалізація, вища освіта, бізнес-адміністрування, вибір студентів.

Manuscript received: 05.06.2020

(C) The author(s) 2020. This article is published with open access at Sumy State University. 